\title{
Clustering the clinical course of chronic urticaria using a longitudinal database: Effects on chronic urticaria remission
}

\author{
Young-Min Ye ${ }^{1}$, Jiwon Yoon ${ }^{1}$, Seong-Dae Woo ${ }^{1}$, Jae-Hyuk Jang ${ }^{1}$, Youngsoo Lee ${ }^{1}$, \\ Hyun-Young Lee ${ }^{2}$, Yoo Seob Shin ${ }^{1}$, Dong Ho Nam ${ }^{1}$, and Hae-Sim Park ${ }^{1}$ \\ ${ }^{1}$ Ajou University School of Medicine and Graduate School of Medicine \\ ${ }^{2}$ Ajou University Hospital
}

August 3, 2020

\begin{abstract}
Background: Little is known about the clinical course of chronic urticaria (CU) and predictors of its prognosis. We evaluated $\mathrm{CU}$ patient clusters based on medication scores for the initial 3 months of treatment to investigate time to remission and relapse rates and to identify predictors for CU remission. Methods: In total, 4552 patients ( $57.9 \%$ female; mean age of 38.6 years) with $\mathrm{CU}$ were included in this retrospective cohort study. The K-medoids algorithm was used for clustering CU patients. KaplanMeier survival analysis with Cox regression was applied to identify predictors of CU remission. Results: Four distinct clusters were identified: patients with consistently low disease activity (cluster $1, \mathrm{n}=1786$ ), with medium-to-low disease activity (cluster $2, \mathrm{n}=1031$ ), with consistently medium disease activity (cluster $3, \mathrm{n}=1332$ ), or with consistently high disease activity (cluster $4, \mathrm{n}=403)$. Mean age, treatment duration, peripheral neutrophil counts, total IgE, and complements levels were significantly higher for cluster 4 than the other three clusters. Median times to remission were also different among the four clusters (2.1 vs 3.3 vs 6.4 vs 9.4 years, respectively, $\mathrm{P}<.001$ ). Sensitization to house dust mites ([?] class 3 ) and female sex were identified as significant predictors of $\mathrm{CU}$ remission. Around $20 \%$ of patients who achieved $\mathrm{CU}$ remission experienced relapse. Conclusion: In this study, we identified four CU patient clusters by analyzing medication scores during the first 3 months of treatment and found that sensitization to house dust mites and female sex can affect $\mathrm{CU}$ prognosis.
\end{abstract}

\section{KEYWORDS}

chronic urticaria, cluster analysis, natural course, relapse, remission

Abbreviations: CI, confidence interval; CU, chronic urticarial; CSU, chronic spontaneous urticarial; HDM, house dust mite; $\mathrm{HR}$, hazard ratio; ICD, international classification of disease; $\mathrm{MC}_{\mathrm{T}}$, tryptase-positive and chymase-negative mast cells; $\mathrm{MC}_{\mathrm{TC}}$, tryptase- and chymase-positive mast cells; MRGX2, mas-related gene $\mathrm{X} 2$.

\section{INTRODUCTION}

Chronic urticaria (CU) is defined as transient itchy wheals and/or angioedema present for at least 6 weeks. ${ }^{1} \mathrm{~A}$ common allergic skin disease, $\mathrm{CU}$ affects between $0.5 \%$ and $5 \%$ of the general population, ${ }^{2}$ and its prevalence in adults and children has been increasing worldwide. ${ }^{3}$ Reportedly, CU poses significant impairments in quality of life, including loss of productivity, psychological distress, and sleep disturbance. ${ }^{4,5}$

Although higher disease severity and the presence of angioedema are associated with a longer duration of urticaria, ${ }^{4}$ research has yet to propose any significant demographic factors with which to predict the prognosis of CU. In a previous study published in 2004, urticaria was cleared after 1 year in $80 \%$ of 5003 Spanish patients with CU, whereas $11 \%$ still had CU after 5 years. ${ }^{6}$ For Korea, a 10-year (2004-2013) follow-up, nationwide, 
population-based study reported a remission rate for CU at 1 year of $52.6 \% .^{7}$ In addition, more than $10 \%$ of $\mathrm{CU}$ patients were found to be affected for longer than 5 years. ${ }^{6-8}$

Guidelines for urticaria recommend step-wise treatment. ${ }^{1,2,9}$ In the first step, the use of approved doses of non-sedative antihistamines is recommended. For individuals whose urticaria remains uncontrolled after 2-4 weeks of treatment, increasing doses up to fourfold is considered. For patients with antihistamineresistant urticaria, the use of omalizumab or cyclosporine is recommended. Based on these stepwise treatment guidelines, a recent study developed medication scores as a means with which to assess treatment intensity or requirements. ${ }^{10}$ Although variability in treatment steps over time has been shown to be important for forecasting the clinical prognosis of $\mathrm{CU}$ patients, to date, no recommendations have been given on how to incorporate medication scores into characterization of the clinical course of the disease.

Research has shown that stratifying a population into more homogenous sub-groups facilitates better prediction of individualized models. ${ }^{11}$ Accordingly, by applying medication scores for the initial 3 months of treatment, we attempted to classify CU patients in a longitudinal database into four individual treatment requirement clusters. In doing so, we aimed to estimate remission rates of $\mathrm{CU}$ for the identified clusters and to identify prognostic factors of CU remission.

\section{METHODS}

\subsection{Study design}

This study was designed as a longitudinal retrospective cohort study of CU patients who had visited a university hospital in Korea from January 1997 to December 2017. We obtained data from electronic medical records of patients who had been diagnosed with CU under the code of L50 in the $10^{\text {th }}$ version of International Classification of Disease (ICD-10). In particular, information on medications prescribed for $\mathrm{CU}$, diagnostic details, laboratory test results, and visit history was extracted and reviewed. Applying unsupervised machine learning techniques, we attempted to identify patterns of the trajectories of the first 3 months of treatment from the index date (i.e., date of starting H1-antihistamines under a L50 diagnosis). Next, we applied this information to evaluate differences in demographics and laboratory test results and to investigate prognostic factors according to the observed clusters. This study was approved by the Ethical Review Board (AJIRB-MED-MDB-18-042).

\subsection{Study population}

In total, 9256 individuals had code L50 as their primary diagnosis. Next, we applied the following inclusion criteria: (a) H1-antihistamine prescription records within 1 year under a principal diagnosis of L50 $(\mathrm{n}=$ 8404); (b) a serial prescription for H1-antihistamines over 6 weeks $(\mathrm{n}=4988)$; and (c) an assessable disease activity over 3 months $(\mathrm{n}=4552)$. Finally, 4552 patients with CU were selected for analysis (see Figure S1 in Supporting Information).

\subsection{Longitudinal medication score assessment}

To quantify the trajectories of disease activity, we employed medication scores for each prescription as described in a previous report. ${ }^{10}$ Score assessment was divided into 10 categories depending on drug dosage and substances. Each point reflected guidelines for urticaria treatment steps and a prior report. ${ }^{2,9,10}$ H1antihistamine doses were described as equivalent doses of loratadine (mg/day): a daily mean dose of H1antihistamine [?]20 mg/day was scored 2 points and that $>20 \mathrm{mg}$ /day was scored 4 points (see Table S1 in Supporting Information). Regarding systemic corticosteroid, 28 days of continuous prescription was calculated. Medication scores for corticosteroids were converted to equivalent doses of prednisolone: $<11 \mathrm{mg} / \mathrm{day}$, 5 points; $11-25 \mathrm{mg} /$ day, 10 points; and $>25 \mathrm{mg} /$ day, 15 points. Among other alternative medications, cyclosporine use was given a score of 8 points, hydroxychloroquine use 6 points, leukotriene receptor antagonist use 2 points, H2-antihistamine use 2 points, and omalizumab use 12 points. Patients who had no medication records for $\mathrm{CU}$ over 1 year despite having visited the hospital for other diseases, were given a medication score of 0 points, and we confirmed $\mathrm{CU}$ remission for the patient. The day of $\mathrm{CU}$ remission was determined 
as the last day when the patient had taken medications. Daily doses of medication were averaged over the first 3 months. Missing values were replaced using linear interpolation methods.

\subsection{Cluster generation}

We applied K-medoids clustering analysis on trajectory medication scores over the first 3 months using the R package "cluster". ${ }^{12}$ Known as partitioning around medoids, K-medoids is utilized to build a set of partitions in data, and each partition represents a cluster. ${ }^{12,13}$ Monthly medication scores (0 to 70 ) over the first 3 months for all 4552 patients with $\mathrm{CU}$ were the object of clustering. To evaluate inter-and intra-cluster distances, the silhouette method was applied. ${ }^{14}$

\subsection{CU remission according to clustering and other clinical factors}

Survival analysis was conducted to identify differences in CU remission rates among the observed clusters. The treatment duration of $\mathrm{CU}$ was defined as the interval from the first date of CU diagnosis to the date of remission. Differences in CU remission rates among clusters were identified using the Kaplan-Meier method. Furthermore, we attempted to discern crucial clinical factors reflective of the noted CU clusters. Demographics, such as age, sex, and treatment duration, as well as laboratory test results, including total $\mathrm{IgE}$ and specific IgE to house dust mites (HDM), peripheral blood cell counts, c-reactive protein, erythrocyte sedimentation ratio, and routine chemistry, were compared among the CU clusters.

Relapse of CU was defined as the reappearance of CU documented by the registration of L50 as a principal diagnosis and prescription for urticaria treatment after remission from $\mathrm{CU}$. We also analyzed times to $\mathrm{CU}$ relapse and clinical characteristics between patients who experienced relapse and those who did not.

\subsection{Statistical analysis}

Welch's ANOVA was used to compare continuous variables among the CU clusters, and the chi-square test was used to compare categorical variables. Multiple comparisons were corrected by Dunnett's and Bonferroni's tests for continuous and categorical variables, respectively. Kaplan-Meier survival curves were drawn to compare remission rates among the CU clusters. We used Cox regression analysis to investigate the relationship between clinical and laboratory parameters and CU remission over a 10-year treatment period. AllP -values under .05 were considered significant. All statistical analyses were conducted with IBM SPSS, version 25 for Windows (IBM SPSS Inc., Chicago, IL, USA) and R 3.5.2 software (R development core team, http://www.r-project.org) .

\section{RESULTS}

\subsection{Clinical characteristics of the study subjects}

Of the 4552 patients included in the present study, 2637 (57.9\%) were female. The mean age of the patients was $38.6 \pm 14.6$ years (Table 1 ). The mean treatment duration of CU was $31.7 \pm 42.6$ months. Other than H1-antihistamines, over the first 3 months of treatment, H2-antihistamines were prescribed for 1553 (34.1\%), leukotriene receptor antagonist for 1013 (22.3\%), hydroxychloroquine for 430 (9.4\%), cyclosporine for 205 $(4.5 \%)$, omalizumab for $203(4.5 \%)$ patients. Systemic corticosteroid treatment for 4 weeks or longer was identified in $311(6.8 \%)$ patients. Gastritis (7.4\%) registered as an ICD-10 code of K29 or K21 was the most prevalent comorbidity, followed by allergic rhinitis (6.3\%), drug allergy (3.4\%), asthma (3.3\%), thyroid diseases $(3.2 \%)$, hypertension $(2.4 \%)$ and diabetes mellitus (1.7\%).

\subsection{Cluster profile}

Four distinct clusters of medication scores were identified (Figure 1): patients with consistently low disease activity (cluster $1, \mathrm{n}=1786$ ), those with medium-to-low disease activity (cluster $2, \mathrm{n}=1031$ ), those with consistently medium disease activity (cluster $3, \mathrm{n}=1332$ ), and those with consistently high disease activity (cluster $4, \mathrm{n}=403$ ). The mean silhouette width of the four clusters was 0.46 and ranged from 0.18 to 0.69 , indicating that each object was well matched to its own cluster and poorly matched to adjacent clusters.

\subsection{Demographics and laboratory test results stratified by the four CU clusters}


Table 1 summarizes the clinical characteristics of study subjects according to the four CU clusters. The mean ages of the clusters ranged from $36.4 \pm 14.9$ (cluster 1) to $42.8 \pm 13.5$ (cluster 4) years and were significantly different among the four clusters $(P<.001)$. The mean ages of CU patients increased steadily from cluster 1 to 4 . Female sex was predominant in all clusters, comprising $54.1 \%$ to $61.6 \%(P=.03)$. There was a higher number of male patients in cluster 4 than in the other clusters. Urticaria treatment duration was longer in cluster $4(39.3 \pm 45.4$ months $)$ than the other three clusters $(31.2 \pm 42.5,31.7 \pm 43.7$, and 30.3 \pm 40.8 months, respectively) $(P=.004)$. The proportion of patients aged 60 years or more was also highest in cluster 4. Almost half of the patients in cluster 4 had been prescribed a systemic steroid, while less than $10 \%$ of patients in the other three clusters received steroid treatment. The use of cyclosporine was recorded for $38.2 \%$ of cluster 4 . Less than $5 \%$ of patients in clusters 1 and 2 had been treated with cyclosporine. In clusters 3 and 4 , respectively, $10.2 \%$ and $7.0 \%$, were found to have received omalizumab.

Laboratory test results at initial diagnosis are described in Table 1. Peripheral white blood cell count and neutrophil percentage were significantly different among the four clusters, with patients in cluster 4 showing the highest white blood cell counts and neutrophil ratio. Meanwhile, the proportions of peripheral lymphocytes, eosinophils and basophils were lower in cluster 4 patients than in patients in the other three clusters. Erythrocyte sedimentation ratio was also higher in the patients of cluster 4 than in those of clusters 1, 2, and $3(P=.003)$.

Serum total IgE levels were significantly higher in cluster 4 patients than in patients in the other three clusters (226.8 \pm 361.5 vs $248.1 \pm 418.2$ vs $249.7 \pm 383.0$ vs $345.9 \pm 603.5$, respectively, $P=.006)$. Levels of complement 3 and complement 4 were higher in the sera from cluster 4 patients than in patients in the other three clusters. Rates of HDM sensitization, determined by levels of specific IgEs to D1 (Dermatophagoides pterygium ) and D2 (D. farina), were not different among the four clusters. Other laboratory parameters, such as creatinine, aspartate aminotransferase, alanine aminotransferase, total bilirubin, and uric acid, were not different among the four clusters.

The prevalences of hypertension, diabetes mellitus, and thyroid diseases were not different among the four clusters. The rates of CU patients combined with allergic rhinitis and drug allergy were higher in clusters 1 and 2, whereas the prevalence of gastritis was higher in clusters 3 and 4 .

\subsection{CU remission according to clustering and other clinical factors}

Moving from clusters 1 to 4, times to CU remission became longer (Figure 2). As reflected in median years and $95 \%$ confidence intervals (CI), times to CU remission were $2.1(1.8-2.6)$ for cluster 1, 3.3 (2.9-4.4) for cluster 2, $6.4(5.6-7.3)$ for cluster 3 , and $9.4(7.7-10.5)$ for cluster $4(P<.001)$. The cumulative incidences of $\mathrm{CU}$ remission during the first year of treatment were $37.5 \%$ for patients in cluster $1,32.6 \%$ in cluster 2 , $11.8 \%$ in cluster 3 , and $4.2 \%$ in cluster 4 (Figure 2). After 5 years of maintenance treatment, the cumulative incidences of $\mathrm{CU}$ remission for the four clusters were $63.1 \%, 56.2 \%, 41.0 \%$, and $30.1 \%$, respectively. More than $70 \%$ of patients in clusters 1 and 2 achieved remission from CU within 10 years of treatment, whereas $66.2 \%$ of patients in cluster 3 and $53.1 \%$ in cluster 4 were found to have achieved remission over the same period.

To identify predictors for CU remission within a 10-year treatment period, we conducted Cox regression analysis with age, sex, CU clusters, total IgE level, and HDM sensitization as covariates, as shown in Table 2. Cluster 2 showed a longer time to CU remission (hazard ratio [HR] $=0.794$ and $95 \%$ CI, 0.698 to 0.902 , $P<.001)$ than cluster 1 as a reference. Compared to cluster 1 , clusters 3 (HR $=0.463,0.401$ to $0.534, P<$ $.001)$ and $4(\mathrm{HR}=0.340,0.265$ to $0.436, P<.001)$ also showed markedly lower probabilities of $\mathrm{CU}$ remission. Together with CU clusters, female sex was found to be an independent prognostic factor for remission in CU patients $(\mathrm{HR}=0.886,0.795$ to $0.988, P=.029)$. Additionally, sensitization to HDM of at least class 3 (specific IgEs to D1 and/or D2 [?] 3.5) was identified as a factor strongly affecting CU remission (HR = $0.731,0.632$ to $0.847, P<.001)$. Serum total $\mathrm{IgE}$ levels and age in $\mathrm{CU}$ patients showed no influence on $\mathrm{CU}$ remission.

\subsection{Relapse of CU according to clustering}


Among 2385 patients who had ever achieved CU remission at least once, 470 (19.7\%) experienced relapse, with a mean time to relapse of $33.0+-28.0$ months. Of the 470 relapsed patients, 238 (50.6\%) finally achieved remission from CU, whereas the other $232(49.4 \%)$ remained in a sustained state of CU. The mean frequency of CU relapse events in patients who experienced remission was 1.19 . Relapse rate $(18.9 \%$ vs $20.4 \%$ vs $20.7 \%$ vs $20.7 \%$, respectively, $P=.880)$ and mean times to CU relapse $(33.6+-29.1$ vs $33.4+-29.1$ vs $31.3+-$ 19.5 vs $35.9+-26.6$ months, respectively, $P=.600$ ) were not different among the four clusters (Figure 3 ). Compared with patients who did not experience relapse, those who did were found to be of younger age at diagnosis and to have frequently used medications other than H1-antihistamines. Sex, presence of allergic diseases, steroid use, total IgE, and HDM sensitization did not differ between these patient groups (Table $3)$.

\section{DISCUSSION}

In this retrospective cohort study, we were able to apply medication scores to partition a large number of CU patients treated at a single university hospital over the most recent 20 years. Using K-medoids clustering analysis based on daily medication scores for the initial 3 months of treatment, we noted four distinct clusters of $\mathrm{CU}$ patients with discernible differences in disease activity. Moreover, we found that CU clusters were useful in predicting long-term treatment outcomes.

To date, studies describing the natural course of $\mathrm{CU}$ are rare, and those that are available report varying results. Differences in study population, design, and period and in definitions of outcomes may account for the variability in the results. Observational studies have reported 5-year remission rates for CU of 29 86\%. ${ }^{15,16}$ Epidemiologic studies have reported remission rates for CU within 3 months ranging from 12.0\% to $50 \%, 7,77$ and 5 -year remission in about $90 \%$ of CU patients. ${ }^{6,7}$ In the present study, we found that the proportion of patients who achieved CU remission differed significantly among the four CU clusters. Oneyear remission rates for clusters 1 and 2, which were reflective of lower disease activity, were similar with those reported in previous epidemiologic studies, ${ }^{7,17}$ while those for clusters 3 and 4 were remarkably less. We believe that because these aforementioned studies were based on data from a health insurance database, in which omalizumab was excluded and some cyclosporine prescriptions were not included, many patients with severe CU may have been lost. This may account for the better CU remission rates in those studies, compared with ours.

A recent review article indicated that female sex, higher age at disease onset, long urticaria duration, and non-steroidal anti-inflammatory drug hypersensitivity may be linked with both severe CU and a longer time to remission. ${ }^{18}$ In the current study, female sex was identified as an indicator predictive of difficulty with achieving CU remission. Similar results of a longer time to remission and more heavily impaired CUspecific quality of life have been reported for women with chronic spontaneous urticaria. ${ }^{19,20}$ Considering that estradiol enhances histamine release from mast cell lines ${ }^{21}$ changes in hormonal milieu in women may be associated with fluctuations in urticaria activity and poor control. Regarding age, we found that mean ages of urticaria onset were higher for clusters 3 and 4 than for clusters 1 and 2. Furthermore, the proportions of patients aged 60 years and older were also higher for clusters 3 and 4 . Nevertheless, age, in itself, had no influence on time to $\mathrm{CU}$ remission.

Among laboratory markers, increases in total IgE, complement 3 and 4 , and peripheral basopenia, lymphocytopenia, and neutrophilia were observed for cluster 4, compared to the other clusters. Kessel et al suggested that elevated total IgE could be a marker for urticaria severity and duration. ${ }^{22}$ In addition, in a prior study, we found elevated total $\mathrm{IgE}$ levels to be significantly correlated with both urticaria activity score and CU-specific quality of life. ${ }^{23}$ Highly cytokinergic IgE antibodies against thyroid autoantigens ${ }^{24,25}$ or interleukin $24^{26}$ and those against staphylococcal enterotoxins ${ }^{27}$ have been suggested as potential causes of CSU in a subpopulation of patients. Moreover, previous results have indicated that these $\operatorname{IgE}$ antibodies show an association with urticaria activity score and may support our findings of elevated total IgE levels in cluster 4 patients, who showed sustained, high disease activity. However, we found no significant association between serum total IgE levels and CU remission or relapse. 
In addition to female sex, a sensitization to HDM was found to be an independent predictor for CU remission, even though proportions thereof did not differ among the four clusters. HDMs are major allergens known to induce allergic rhinitis, asthma, and atopic dermatitis. ${ }^{28}$ Sensitization to HDM, particularly toDermatophagoides, has increased greatly with rapid industrialization in many countries, ${ }^{29-32}$ as has the prevalence of CU. ${ }^{3,17}$ There are several reports on the relationships between HDMs and CU. ${ }^{33-38}$ Previous studies have described positive skin reactivity and/or serum specific IgE to HDM in $18 \%$ to $63 \%$ of patients with CU. ${ }^{33-35,37,38}$ In a Turkish study, only sensitivity to HDM was more common in CU patients without allergic diseases than in healthy controls, whereas rates of skin reactivity to other aeroallergens, such as pollen, mold, and animal dander, were similar. ${ }^{34}$ Song et al reported significantly higher urticaria activity scores in HDM-sensitive CU patients than in patients with a negative skin test to HDM. ${ }^{35}$ Furthermore, a clinical benefit for mite immunotherapy in CU patients with mite hypersensitivity has been proven. ${ }^{36,39}$

The release of histamine and inflammatory mediators from activated mast cells are regarded as the primary mechanism for CU. ${ }^{40,41}$ Currently, primed mast cells ready to release mediators upon exposure to various stimuli are thought to be at play. ${ }^{41}$ Sensitization of mast cells with monomeric IgE in the absence of antigen has been found to promote mast cell proliferation, differentiation, survival, and mediator production. ${ }^{41,42}$ As HDMs are considered as key players in the progression of atopic march, ${ }^{43}$ the presence of specific IgE against HDM may also play a role in priming mast cells in CU patients. However, the clinical relevance of HDM sensitivity to the etiology and management of CU still needs to be established. Although the presence of specific IgE to HDM in CU patients may simply reflect an epiphenomenon of exposure to environmental dust, not a direct cause of the disease, the literature does support a significant association between sensitization to HDM and difficulty with achieving CU remission. Indeed, research has proven that HDMs activate nociceptors to release substance $\mathrm{P}$ from sensory neuron, ${ }^{44}$ and there is direct evidence that mast cells are activated by substance P via mas-related gene X2 (MRGX2) signaling, thereby initiating type 2 immunemediated allergic inflammation in the skin. ${ }^{44}$ Furthermore, MRGX2 has been found to be highly expressed in CSU skin, particularly in severe CSU, ${ }^{45}$ and in CU patients who express MRGX2, exposure to HDM, can induce mast cell degranulation. Since $\mathrm{CU}$ has been widely recognized as a chronic allergic skin disease, we now need to investigate further the relationship between HDM sensitization and CU.

To date, only a few studies have investigated CU relapse, and how CU relapse ought to be defined is still unclear. Kim et $\mathrm{al}^{46}$ has defined recurrent $\mathrm{CU}$ as urticaria recurring at least 6 months after stopping controller medications and resolution of prior urticarial symptoms. They reported that $13 \%$ of 341 patients had recurrent $\mathrm{CU}$ under this definition. In our study, relapse of $\mathrm{CU}$ was defined as the reappearance of H1-antihiatamine and/or immunomodulators prescriptions for urticaria under the primary diagnosis of L50 after previously achieving CU remission (no medication for more than a year). Similar with Kim et al's report, we found the relapse rate of $\mathrm{CU}$ patients overall to be $19.7 \% .{ }^{46}$ Furthermore, we also found the use of immunomodulators to pose a higher risk of CU relapse, similar to a previous study. ${ }^{46}$ Considering that relapse rates and mean times to relapse of CU did not differ among the four clusters, we believe that maintaining proper treatment steps for controlling urticarial symptoms is important and that patients who need immunomodulators, such as omalizumab and cyclosporin, should be more cautious about stopping medications.

There are potential limitations in the present study. First, the operational definitions of CU, remission, and relapse from a retrospective investigation were incontrovertibly different from the actual epidemiology of the disease. Thus, we used strict definitions to minimize misclassification of $\mathrm{CU}$ and to avoid overestimation of CU remission. As a result, about half of all cases with L50 as a principal diagnosis were excluded. Since this study institution was a tertiary referral center for CU, some patients with mild CU and some referred patients who had already maintained H1-antihistamines at the initial visit, but had not stayed for more than 3 months, might have been excluded. Due to a nature of retrospective study, differences in compliance with treatment among patients could not be considered. Nonetheless, we were able to identify four distinct clusters of $\mathrm{CU}$ based on medication scores during the first 3 months, and then, a longitudinal cohort covering up to 21 years was established. Second, this study did not include information specific to CU, such as urticaria activity score, the presence of autoantibodies, and urticaria subtypes. Third, the subjects of the present 
study were from a single ethnicity. In the future, expanding this study to include multiple clinical sites from various regions would be helpful to improving the generalizability of the CU clusters.

In conclusion, we established four CU clusters using the medication scores for the first 3 months of treatment as a reliable surrogate marker for CU progress. These four clusters were able to depict differences in clinical features of $\mathrm{CU}$, including demographics, laboratory results, and the remission rate of CU. A strong sensitization against HDM and female sex were also found to affect the prognosis of CU. The use of immunomodulators was implicated in the risk for CU relapse.

\section{ACKNOWLEDGMENTS}

This work was supported by a grant from the National Research Foundation of Korea (NRF) funded by the Korea government (MSIP) (NRF-2018R1A2B6006199) and partly supported by a grant from the Korea Health Technology R\&D Project through the Korea Health Industry Development Institute (KHIDI) funded by the Ministry of Health \& Welfare, Republic of Korea (HI16C0992).

\section{CONFLICT OF INTERST}

The authors declare that they have no conflicts of interest.

\section{REFERENCES}

1. Zuberbier T, Aberer W, Asero R, et al. The EAACI/GA2LEN/EDF/WAO guideline for the definition, classification, diagnosis and management of urticaria. Allergy . 2018;73:1393-1414.

2. Song WJ, Choi M, Lee DH, et al. The KAAACI/KDA evidence-based practice guidelines for chronic spontaneous urticaria in Korean adults and children: part 1. definition, methodology and first-line management.Allergy Asthma Immunol Res . 2020;12:563-578.

3. Fricke J, Avila G, Keller T, et al. Prevalence of chronic urticaria in children and adults across the globe: systematic review with meta-analysis. Allergy . 2020;75:423-432.

4. Maurer M, Weller K, Bindslev-Jensen C, et al. Unmet clinical needs in chronic spontaneous urticaria. a GA2LEN task force report 1.Allergy . 2011;66:317-330.

5. Lee MS, Yoon J, Kim J, et al. Health-related utility of EQ-5D in Korean adults with chronic urticaria: mapping from urticaria outcome measures. Allergy Asthma Immunol Res . 2020;12:599-607.

6. Gaig P, Olona M, Munoz Lejarazu D, et al. Epidemiology of urticaria in Spain. J Investig Allergol Clin Immunol . 2004;14:214-220.

7. Eun SJ, Lee JY, Kim DY, Yoon HS. Natural course of new-onset urticaria: results of a 10-year follow-up, nationwide, population-based study. Allergol Int . 2019;68:52-58.

8. Toubi E, Kessel A, Avshovich N, et al. Clinical and laboratory parameters in predicting chronic urticaria duration: a prospective study of 139 patients. Allergy . 2004;59:869-873.

9. Choi JH, Lee DH, Song WJ, et al. The KAAACI/KDA evidence-based practice guidelines for chronic spontaneous urticaria in Korean adults and children: part 2. management of H1-antihistamine-refractory chronic urticaria. Allergy Asthma Immunol Res . 2020;12:e51. doi: 10.4168/aair.2020.4112.e4151.

10. Sussman G, Hebert J, Barron C, et al. Real-life experiences with omalizumab for the treatment of chronic urticaria. Ann Allergy Asthma Immunol . 2014;112:170-174.

11. Lee J, Maslove DM, Dubin JA. Personalized mortality prediction driven by electronic medical data and a patient similarity metric.PLoS One . 2015;10:e0127428.

12. Soni KG, Patel A. Comparative analysis of K-means and K-medoids Algorithm on iris data. Int $J$ Comput Intell Res . 2017;13:899-906. 
13. Park HS, Jun CH. A simple and fast algorithm for K-medoids clustering. Expert Syst Appl . 2009;36:33363341.

14. Rousseeuw PJ. Silhouettes: a graphical aid to the interpretation and validation of cluster analysis. $J$ Comput Appl Math . 1987;20:53-65.

15. Van Der Valk P, Moret G, Kiemeney LJ. The natural history of chronic urticaria and angioedema in patients visiting a tertiary referral centre. Bri J Dermatol . 2002;146:110-113.

16. Toubi E, Kessel A, Avshovich N, et al. Clinical and laboratory parameters in predicting chronic urticaria duration: a prospective study of 139 patients. Allergy . 2004;59:869-873.

17. Lee N, Lee JD, Lee HY, Kang DR, Ye Y-M. Epidemiology of chronic urticaria in Korea using the Korean Health Insurance Database, 2010-2014. Allergy Asthma Immunol Res . 2017;9:438-445.

18. Sanchez-Borges M, Caballero-Fonseca F, Capriles-Hulett A, Gonzalez-Aveledo L, Maurer M. Factors linked to disease severity and time to remission in patients with chronic spontaneous urticaria.J Eur Acad Dermatol Venereol . 2017;31:964-971.

19. Gregoriou S, Rigopoulos D, Katsambas A, et al. Etiologic aspects and prognostic factors of patients with chronic urticaria: nonrandomized, prospective, descriptive study. J Cutan Med Surg . 2009;13:198-203.

20. Mlynek A, Magerl M, Hanna M, et al. The German version of the chronic urticaria quality-of-life questionnaire: factor analysis, validation, and initial clinical findings. Allergy . 2009;64:927-936.

21. Chen W, Mempel M, Schober W, Behrendt H, Ring J. Gender difference, sex hormones, and immediate type hypersensitivity reactions. Allergy . 2008;63:1418-1427.

22. Kessel A, Helou W, Bamberger E, et al. Elevated serum total IgE-a potential marker for severe chronic urticaria. Int Arch Allergy Immunol . 2010;153:288-293.

23. Choi WS, Lim ES, Ban GY, et al. Disease-specific impairment of the quality of life in adult patients with chronic spontaneous urticaria.Korean J Intern Med . 2018;33:185-192.

24. Shin YS, Suh DH, Yang EM, Ye YM, Park HS. Serum specific IgE to thyroid peroxidase activates basophils in aspirin intolerant urticaria.J Korean Med Sci . 2015;30:705-709.

25. Sanchez J, Sanchez A, Cardona R. Causal relationship between anti-TPO IgE and chronic urticaria by in vitro and in vivo tests. Allergy Asthma Immunol Res . 2019;11:29-42.

26. Schmetzer O, Lakin E, Topal FA, et al. IL-24 is a common and specific autoantigen of IgE in patients with chronic spontaneous urticaria. J Allergy Clin Immunol . 2018;142:876-882.

27. Altrichter S, Hawro T, Liedtke M, et al. In chronic spontaneous urticaria, IgE against staphylococcal enterotoxins is common and functional. Allergy . 2018;73:1497-1504.

28. Acevedo N, Zakzuk J, Caraballo L. House dust mite allergy under changing environments. Allergy Asthma Immunol Res . 2019;11:450-469.

29. Tham EH, Lee AJ, Bever HV. Aeroallergen sensitization and allergic disease phenotypes in Asia. Asian Pac J Allergy Immunol . 2016;34:181-189.

30. Kidon MI, Chiang WC, Liew WK, et al. Sensitization to dust mites in children with allergic rhinitis in Singapore: does it matter if you scratch while you sneeze? Clin Exp Allergy . 2005;35:434-440.

31. Park HJ, Lim HS, Park KH, Lee JH, Park JW, Hong CS. Changes in allergen sensitization over the last 30 years in Korea respiratory allergic patients: a single-center. Allergy Asthma Immunol Res . 2014;6:434-443.

32. Kim J, Hahm MI, Lee SY, et al. Sensitization to aeroallergens in Korean children: a population-based study in 2010. J Korean Med Sci . 2011;26:1165-1172. 
33. Numata T, Yamamoto S, Yamura T. The role of mite, house dust and Candida allergens in chronic urticaria. J Dermatol . 1980;7:197-202.

34. Caliskaner Z, Ozturk S, Turan M, Karaayvaz M. Skin test positivity to aeroallergens in the patients with chronic urticaria without allergic respiratory disease. J Investig Allergol Clin Immunol . 2004;14:50-54.

35. Song Z, Zhai Z, Zhong H, Zhou Z, Chen W, Hao F. Evaluation of autologous serum skin test and skin prick test reactivity to house dust mite in patients with chronic spontaneous urticaria. PLoS One . 2013;8:e64142.

36. Kasperska-Zajac A, Brzoza Z. Remission of chronic urticaria in the course of house dust mite immunotherapy-Mere coincidence or something more to it? Vaccine . 2009;27:7240-7241.

37. Kulthanan K, Wachirakaphan C. Prevalence and clinical characteristics of chronic urticaria and positive skin prick testing to mites. Acta Derm Venereol . 2008;88:584-588.

38. Mahesh PA, Kushalappa PA, Holla AD, Vedanthan PK. House dust mite sensitivity is a factor in chronic urticaria. Indian J Dermatol Venereol Leprol . 2005;71:99-101.

39. Lodi A, Di Berardino L, Chiarelli G, et al. Chronic urticaria and allergy to Acari. experience with a specific desensitization therapy. G Ital Dermatol Venereol . 1990;125:187-189.

40. Church MK, Kolkhir P, Metz M, Maurer M. The role and relevance of mast cells in urticaria. Immunol Rev . 2018;282:232-247.

41. Chang TW, Chen C, Lin CJ, Metz M, Church MK, Maurer M. The potential pharmacologic mechanisms of omalizumab in patients with chronic spontaneous urticaria. J Allergy Clin Immunol . 2015;135:337-342.

42. Jayapal M, Tay HK, Reghunathan R, et al. Genome-wide gene expression profiling of human mast cells stimulated by IgE or FcepsilonRI-aggregation reveals a complex network of genes involved in inflammatory responses. BMC Genomics . 2006;7:210.

43. Miller JD. The role of dust mites in allergy. Clin Rev Allergy Immunol . 2019;57:312-329.

44. Serhan N, Basso L, Sibilano R, et al. House dust mites activate nociceptor-mast cell clusters to drive type 2 skin inflammation. Nat Immunol . 2019;20:1435-1443.

45. Fujisawa D, Kashiwakura J-I, Kita H, et al. Expression of Mas-related gene X2 on mast cells is upregulated in the skin of patients with severe chronic urticaria. J Allergy Clin Immunol . 2014;134:622633.e629.

46. Kim JK, Har D, Brown LS, Khan DA. Recurrence of chronic urticaria: incidence and associated factors. J Allergy Clin Immunol Pract . 2018;6:582-585.

TABLE 1 Clinical characteristics of the study subjects according to the four clusters

\begin{tabular}{|c|c|c|c|c|c|c|c|c|}
\hline Charac & $\begin{array}{l}\text { Overall } \\
\text { popula- } \\
\text { stican }\end{array}$ & $\begin{array}{l}\text { Cluster } 1 \\
(\mathrm{n}= \\
1786)\end{array}$ & $\begin{array}{l}\text { Cluster } 2 \\
(\mathrm{n}= \\
1031)\end{array}$ & $\begin{array}{l}\text { Cluster } 3 \\
(\mathrm{n}= \\
1332)\end{array}$ & $\begin{array}{l}\text { Cluster } 4 \\
(\mathrm{n}= \\
\mathbf{4 0 3})\end{array}$ & ${ }^{*} P$-value & $\begin{array}{l}+P \\
\text { values } \\
\text { for } \\
\text { Cluster } 4 \\
\text { vs }\end{array}$ & $\begin{array}{l}+P \\
\text { values } \\
\text { for } \\
\text { Cluster } 4 \\
\text { vs }\end{array}$ \\
\hline \multicolumn{2}{|c|}{ Characteristican } & & & & & & 1 & 2 \\
\hline $\begin{array}{l}\text { Female } \\
(\%)\end{array}$ & $\begin{array}{l}2637 \\
(57.9)\end{array}$ & $\begin{array}{l}1026 \\
(57.4)\end{array}$ & $\begin{array}{l}635 \\
(61.6)\end{array}$ & $\begin{array}{l}758 \\
(56.9)\end{array}$ & $\begin{array}{l}218 \\
(54.1)\end{array}$ & .030 & 1.000 & .067 \\
\hline $\begin{array}{l}\text { Age, } \\
\text { mean }\end{array}$ & $\begin{array}{l}38.6 \pm \\
14.6\end{array}$ & $\begin{array}{l}36.4 \pm \\
14.9\end{array}$ & $\begin{array}{l}38.4 \pm \\
14.6\end{array}$ & $\begin{array}{l}40.3 \pm \\
14.1\end{array}$ & $\begin{array}{l}42.8 \pm \\
13.5\end{array}$ & $<.001$ & $<.001$ & $<.001$ \\
\hline
\end{tabular}




\begin{tabular}{|c|c|c|c|c|c|c|c|c|}
\hline Characteris & $\begin{array}{l}\text { Overall } \\
\text { popula- } \\
\text { sticn }\end{array}$ & $\begin{array}{l}\text { Cluster } 1 \\
(\mathrm{n}= \\
1786)\end{array}$ & $\begin{array}{l}\text { Cluster 2 } \\
(\mathrm{n}= \\
1031)\end{array}$ & $\begin{array}{l}\text { Cluster 3 } \\
(\mathrm{n}= \\
1332)\end{array}$ & $\begin{array}{l}\text { Cluster } 4 \\
(\mathrm{n}= \\
403)\end{array}$ & ${ }^{*} P$-value & $\begin{array}{l}{ }^{+} P \\
\text { values } \\
\text { for } \\
\text { Cluster } 4 \\
\text { vs }\end{array}$ & $\begin{array}{l}{ }^{+} P \\
\text { values } \\
\text { for } \\
\text { Cluster } 4 \\
\text { vs }\end{array}$ \\
\hline $\begin{array}{l}<20 \\
\text { years } \\
(\%)\end{array}$ & $\begin{array}{l}510 \\
(11.2)\end{array}$ & $\begin{array}{l}293 \\
(16.4)\end{array}$ & $\begin{array}{l}114 \\
(11.1)\end{array}$ & $\begin{array}{l}91 \\
(6.8)\end{array}$ & $\begin{array}{l}12 \\
(3.0)\end{array}$ & $<.001$ & $<.001$ & $<.001$ \\
\hline $\begin{array}{l}20-39 \\
(\%)\end{array}$ & $\begin{array}{l}1907 \\
(41.9)\end{array}$ & $\begin{array}{l}754 \\
(42.2)\end{array}$ & $\begin{array}{l}431 \\
(41.8)\end{array}$ & $\begin{array}{l}556 \\
(41.7)\end{array}$ & $\begin{array}{l}166 \\
(41.2)\end{array}$ & .982 & 1.000 & 1.000 \\
\hline $\begin{array}{l}40-59 \\
(\%)\end{array}$ & $\begin{array}{l}1763 \\
(38.7)\end{array}$ & $\begin{array}{l}620 \\
(34.7)\end{array}$ & $\begin{array}{l}407 \\
(39.5)\end{array}$ & $\begin{array}{l}563 \\
(42.3)\end{array}$ & $\begin{array}{l}173 \\
(42.9)\end{array}$ & $<.001$ & .014 & 1.000 \\
\hline $\begin{array}{l}{[?] 60} \\
(\%)\end{array}$ & $\begin{array}{l}372 \\
(8.2)\end{array}$ & $\begin{array}{l}119 \\
(6.7)\end{array}$ & $\begin{array}{l}79 \\
(7.7)\end{array}$ & $\begin{array}{l}122 \\
(9.2)\end{array}$ & $\begin{array}{l}52 \\
(12.9)\end{array}$ & $<.001$ & $<.001$ & .016 \\
\hline $\begin{array}{l}\text { CU du- } \\
\text { ration } \\
\text { (month) } \\
\text { Medication } \\
\text { use } \\
(\%)\end{array}$ & $\begin{array}{l}31.7 \pm \\
42.6\end{array}$ & $\begin{array}{l}31.2 \pm \\
42.5\end{array}$ & $\begin{array}{l}31.7 \pm \\
43.7\end{array}$ & $\begin{array}{l}30.3 \pm \\
40.8\end{array}$ & $\begin{array}{l}39.3 \pm \\
45.4\end{array}$ & .004 & .006 & .023 \\
\hline $\mathrm{H} 1 \mathrm{AH}$ & $\begin{array}{l}4552 \\
(100)\end{array}$ & $\begin{array}{l}1786 \\
(100)\end{array}$ & $\begin{array}{l}1031 \\
(100)\end{array}$ & $\begin{array}{l}1332 \\
(100)\end{array}$ & $\begin{array}{l}403 \\
(100)\end{array}$ & NA & NA & NA \\
\hline $\mathrm{H} 2 \mathrm{AH}$ & $\begin{array}{l}1553 \\
(34.1)\end{array}$ & $\begin{array}{l}313 \\
(17.5)\end{array}$ & $\begin{array}{l}371 \\
(36.0)\end{array}$ & $\begin{array}{l}604 \\
(45.3)\end{array}$ & $\begin{array}{l}265 \\
(65.8)\end{array}$ & $<.001$ & $<.001$ & $<.001$ \\
\hline LTRA & $\begin{array}{l}1013 \\
(22.3)\end{array}$ & $\begin{array}{l}182 \\
(10.2)\end{array}$ & $\begin{array}{l}322 \\
(31.2)\end{array}$ & $\begin{array}{l}347 \\
(26.1)\end{array}$ & $\begin{array}{l}162 \\
(40.2)\end{array}$ & $<.001$ & $<.001$ & .009 \\
\hline Hydroxychlor & $\begin{array}{l}\text { re30ine } \\
(9.4)\end{array}$ & $\begin{array}{l}13 \\
(0.7)\end{array}$ & $\begin{array}{l}40 \\
(3.9)\end{array}$ & $\begin{array}{l}196 \\
(14.7)\end{array}$ & $\begin{array}{l}181 \\
(44.9)\end{array}$ & $<.001$ & $<.001$ & $<.001$ \\
\hline Cyclosporine & 205 & $0(0.0)$ & $4(0.4)$ & $\begin{array}{l}47 \\
(3.5)\end{array}$ & $\begin{array}{l}154 \\
(38.2)\end{array}$ & $<.001$ & $<.001$ & $<.001$ \\
\hline Omalizumab & $\begin{array}{l}203 \\
(4.5)\end{array}$ & $\begin{array}{l}20 \\
(1.1)\end{array}$ & $\begin{array}{l}49 \\
(4.7)\end{array}$ & $\begin{array}{l}93 \\
(7.0)\end{array}$ & $\begin{array}{l}41 \\
(10.2)\end{array}$ & $<.001$ & $<.001$ & .001 \\
\hline Corticosteroic & $\begin{array}{l}\mathrm{id} 311 \\
(6.8)\end{array}$ & $\begin{array}{l}10 \\
(5.6)\end{array}$ & $\begin{array}{l}18 \\
(1.7)\end{array}$ & $\begin{array}{l}90 \\
(6.8)\end{array}$ & $\begin{array}{l}193 \\
(47.9)\end{array}$ & $<.001$ & $<.001$ & $<.001$ \\
\hline $\begin{array}{l}\text { Laboratory } \\
\text { test, } \\
\text { mean }\end{array}$ & $\begin{array}{l}\text { Laboratory } \\
\text { test, } \\
\text { mean }\end{array}$ & $\begin{array}{l}\text { Laboratory } \\
\text { test, } \\
\text { mean }\end{array}$ & $\begin{array}{l}\text { Laboratory } \\
\text { test, } \\
\text { mean }\end{array}$ & $\begin{array}{l}\text { Laboratory } \\
\text { test, } \\
\text { mean }\end{array}$ & $\begin{array}{l}\text { Laboratory } \\
\text { test, } \\
\text { mean }\end{array}$ & $\begin{array}{l}\text { Laboratory } \\
\text { test, } \\
\text { mean }\end{array}$ & $\begin{array}{l}\text { Laboratory } \\
\text { test, } \\
\text { mean }\end{array}$ & $\begin{array}{l}\text { Laboratory } \\
\text { test, } \\
\text { mean }\end{array}$ \\
\hline$\pm \mathrm{SD}$ & $\pm \mathrm{SD}$ & $\pm \mathrm{SD}$ & $\pm \mathrm{SD}$ & $\pm \mathrm{SD}$ & $\pm \mathrm{SD}$ & $\pm \mathrm{SD}$ & $\pm \mathrm{SD}$ & $\pm \mathrm{SD}$ \\
\hline $\begin{array}{l}\text { WBC } \\
\left(10^{3} / \mu \mathrm{L}\right)\end{array}$ & $\begin{array}{l}7.6 \pm \\
3.4\end{array}$ & $\begin{array}{l}7.0 \pm \\
2.7\end{array}$ & $\begin{array}{l}7.9 \pm \\
3.8\end{array}$ & $\begin{array}{l}7.8 \pm \\
3.4\end{array}$ & $\begin{array}{l}8.9 \pm \\
4.1\end{array}$ & $<.001$ & $<.001$ & $<.001$ \\
\hline $\begin{array}{l}\text { Neutrophil } \\
(\%)\end{array}$ & $\begin{array}{l}59.3 \pm \\
11.5\end{array}$ & $\begin{array}{l}57.4 \pm \\
10.5\end{array}$ & $\begin{array}{l}60.2 \pm \\
12.0\end{array}$ & $\begin{array}{l}60.0 \pm \\
11.5\end{array}$ & $\begin{array}{l}63.1 \pm \\
12.2\end{array}$ & $<.001$ & $<.001$ & $<.001$ \\
\hline $\begin{array}{l}\text { Lymphocyte } \\
(\%)\end{array}$ & $\begin{array}{l}31.0 \pm \\
9.8\end{array}$ & $\begin{array}{l}32.6 \pm \\
9.2\end{array}$ & $\begin{array}{l}30.2 \pm \\
10.1\end{array}$ & $\begin{array}{l}30.4 \pm \\
9.8\end{array}$ & $\begin{array}{l}28.0 \pm \\
10.4\end{array}$ & $<.001$ & $<.001$ & .002 \\
\hline $\begin{array}{l}\text { Eosinophil } \\
(\%)\end{array}$ & $\begin{array}{l}2.3 \pm \\
2.3\end{array}$ & $\begin{array}{l}2.5 \pm \\
2.4\end{array}$ & $\begin{array}{l}2.4 \pm \\
2.5\end{array}$ & $\begin{array}{l}2.2 \pm \\
2.1\end{array}$ & $\begin{array}{l}2.0 \pm \\
2.4\end{array}$ & .001 & .002 & .056 \\
\hline $\begin{array}{l}\text { Basophil } \\
(\%)\end{array}$ & $\begin{array}{l}0.5 \pm \\
0.3\end{array}$ & $\begin{array}{l}0.6 \pm \\
0.4\end{array}$ & $\begin{array}{l}0.51 \pm \\
0.3\end{array}$ & $\begin{array}{l}0.5 \pm \\
0.3\end{array}$ & $\begin{array}{l}0.4 \pm \\
0.2\end{array}$ & $<.001$ & $<.001$ & $<.001$ \\
\hline $\begin{array}{l}\text { Platelet } \\
\left(10^{3} / \mu \mathrm{L}\right)\end{array}$ & $\begin{array}{l}256.6 \\
\pm 62.0\end{array}$ & $\begin{array}{l}253.9 \\
\pm 61.6\end{array}$ & $\begin{array}{l}260.9 \\
\pm 61.1\end{array}$ & $\begin{array}{l}254.9 \\
\pm 61.2\end{array}$ & $\begin{array}{l}263.0 \\
\pm 67.5\end{array}$ & .007 & .091 & .995 \\
\hline
\end{tabular}




\begin{tabular}{|c|c|c|c|c|c|c|c|c|}
\hline Characteris & $\begin{array}{l}\text { Overall } \\
\text { popula- } \\
\text { stican }\end{array}$ & $\begin{array}{l}\text { Cluster } 1 \\
(\mathrm{n}= \\
\mathbf{1 7 8 6 )}\end{array}$ & $\begin{array}{l}\text { Cluster } 2 \\
(\mathrm{n}= \\
1031)\end{array}$ & $\begin{array}{l}\text { Cluster } 3 \\
(\mathrm{n}= \\
\mathbf{1 3 3 2})\end{array}$ & $\begin{array}{l}\text { Cluster } 4 \\
(\mathrm{n}= \\
\mathbf{4 0 3})\end{array}$ & ${ }^{*} P$-value & $\begin{array}{l}{ }^{+} P \\
\text { values } \\
\text { for } \\
\text { Cluster } 4 \\
\text { vs }\end{array}$ & $\begin{array}{l}{ }^{+} P \\
\text { values } \\
\text { for } \\
\text { Cluster } 4 \\
\text { vs }\end{array}$ \\
\hline $\begin{array}{l}\text { ESR } \\
(\mathrm{mm} / \mathrm{hr})\end{array}$ & $\begin{array}{l}11.2 \pm \\
10.5\end{array}$ & $\begin{array}{l}10.6 \pm \\
10.0\end{array}$ & $\begin{array}{l}11.6 \pm \\
11.1\end{array}$ & $\begin{array}{l}11.2 \pm \\
10.4\end{array}$ & $\begin{array}{l}12.8 \pm \\
10.9\end{array}$ & .003 & .004 & .427 \\
\hline $\begin{array}{l}\text { BUN } \\
(\mathrm{mg} / \mathrm{dL})\end{array}$ & $\begin{array}{l}12.6 \pm \\
3.9\end{array}$ & $\begin{array}{l}12.3 \pm \\
3.4\end{array}$ & $\begin{array}{l}12.7 \pm \\
4.2\end{array}$ & $\begin{array}{l}12.6 \pm \\
4.1\end{array}$ & $\begin{array}{l}13.0 \pm \\
4.4\end{array}$ & .012 & .027 & .699 \\
\hline $\begin{array}{l}\text { Creatinine } \\
(\mathrm{mg} / \mathrm{dL})\end{array}$ & $\begin{array}{l}2.1 \pm \\
13.6\end{array}$ & $\begin{array}{l}2.3 \pm \\
16.0\end{array}$ & $\begin{array}{l}2.3 \pm \\
13.8\end{array}$ & $\begin{array}{l}1.6 \pm \\
9.5\end{array}$ & $\begin{array}{l}1.8 \pm \\
12.9\end{array}$ & .415 & .982 & .993 \\
\hline $\begin{array}{l}\text { Uric } \\
\text { acid } \\
(\mathrm{mg} / \mathrm{dL})\end{array}$ & $\begin{array}{l}4.8 \pm \\
1.4\end{array}$ & $\begin{array}{l}4.8 \pm \\
1.4\end{array}$ & $\begin{array}{l}4.7 \pm \\
1.4\end{array}$ & $\begin{array}{l}4.75 \pm \\
1.42\end{array}$ & $\begin{array}{l}4.8 \pm \\
1.4\end{array}$ & .222 & .909 & 1.000 \\
\hline $\begin{array}{l}\text { Total } \\
\text { Protein } \\
(\mathrm{g} / \mathrm{dL})\end{array}$ & $\begin{array}{l}7.3 \pm \\
0.4\end{array}$ & $\begin{array}{l}7.3 \pm \\
0.4\end{array}$ & $\begin{array}{l}7.3 \pm \\
0.5\end{array}$ & $\begin{array}{l}7.26 \pm \\
0.43\end{array}$ & $\begin{array}{l}7.2 \pm \\
0.5\end{array}$ & $<.001$ & $<.001$ & .207 \\
\hline $\begin{array}{l}\text { Total } \\
\text { Biliru- } \\
\text { bin } \\
(\mathrm{mg} / \mathrm{dL})\end{array}$ & $\begin{array}{l}0.7 \pm \\
0.4\end{array}$ & $\begin{array}{l}0.7 \pm \\
0.4\end{array}$ & $\begin{array}{l}0.7 \pm \\
0.3\end{array}$ & $\begin{array}{l}0.79 \pm \\
0.3\end{array}$ & $\begin{array}{l}0.7 \pm \\
0.4\end{array}$ & .152 & .978 & .997 \\
\hline $\begin{array}{l}\text { Total } \\
\text { IgE } \\
(\mathrm{kU} / \mathrm{L})\end{array}$ & $\begin{array}{l}249.6 \\
\pm \\
410.3\end{array}$ & $\begin{array}{l}226.8 \\
\pm \\
361.5\end{array}$ & $\begin{array}{l}248.1 \\
\pm \\
418.2\end{array}$ & $\begin{array}{l}249.7 \\
\pm \\
383.0\end{array}$ & $\begin{array}{l}345.9 \\
\pm \\
603.5\end{array}$ & .006 & .005 & .049 \\
\hline $\begin{array}{l}\text { IgE to } \\
\mathrm{HDM} \\
<3.5 \\
\mathrm{kU} / \mathrm{L}\end{array}$ & $\begin{array}{l}2496 \\
(77.3 \%)\end{array}$ & $\begin{array}{l}967 \\
(78.1)\end{array}$ & $\begin{array}{l}570 \\
(76.6)\end{array}$ & $\begin{array}{l}728 \\
(76.6)\end{array}$ & $\begin{array}{l}231 \\
(78.3)\end{array}$ & .768 & 1.000 & 1.000 \\
\hline $\begin{array}{l}\text { IgE to } \\
\text { HDM } \\
{[?] 3.5} \\
\mathrm{kU} / \mathrm{L}\end{array}$ & $\begin{array}{l}732 \\
(22.7 \%)\end{array}$ & $\begin{array}{l}271 \\
(21.9)\end{array}$ & $\begin{array}{l}174 \\
(23.4)\end{array}$ & $\begin{array}{l}223 \\
(23.4)\end{array}$ & $\begin{array}{l}64 \\
(21.7)\end{array}$ & .768 & 1.000 & 1.000 \\
\hline $\begin{array}{l}\text { ALT } \\
(\mathrm{U} / \mathrm{L})\end{array}$ & $\begin{array}{l}26.0 \pm \\
38.4\end{array}$ & $\begin{array}{l}26.7 \pm \\
53.5\end{array}$ & $\begin{array}{l}24.8 \pm \\
25.6\end{array}$ & $\begin{array}{l}25.4 \pm \\
23.5\end{array}$ & $\begin{array}{l}27.6 \pm \\
24.1\end{array}$ & .238 & .996 & .319 \\
\hline $\begin{array}{l}\mathrm{AST} \\
(\mathrm{U} / \mathrm{L})\end{array}$ & $\begin{array}{l}24.2 \pm \\
29.0\end{array}$ & $\begin{array}{l}25.4 \pm \\
40.1\end{array}$ & $\begin{array}{l}23.7 \pm \\
26.0\end{array}$ & $\begin{array}{l}23.2 \pm \\
11.5\end{array}$ & $\begin{array}{l}23.6 \pm \\
16.4\end{array}$ & .224 & .658 & 1.000 \\
\hline $\begin{array}{l}\text { Complement } \\
3 \\
(\mathrm{mg} / \mathrm{dL})\end{array}$ & $\begin{array}{l}115.0 \\
\pm 25.0\end{array}$ & $\begin{array}{l}113.4 \\
\pm 23.8\end{array}$ & $\begin{array}{l}114.0 \\
\pm 23.8\end{array}$ & $\begin{array}{l}115.2 \\
\pm 25.0\end{array}$ & $\begin{array}{l}123.05 \\
\pm 30.2\end{array}$ & $<.001$ & $<.001$ & $<.001$ \\
\hline $\begin{array}{l}\text { Complement } \\
4 \\
(\mathrm{mg} / \mathrm{dL})\end{array}$ & $\begin{array}{l}26.86 \\
\pm 8.9\end{array}$ & $\begin{array}{l}26.0 \pm \\
8.3\end{array}$ & $\begin{array}{l}26.4 \pm \\
8.7\end{array}$ & $\begin{array}{l}27.3 \pm \\
9.1\end{array}$ & $\begin{array}{l}29.1 \pm \\
9.9\end{array}$ & $<.001$ & $<.001$ & $<.001$ \\
\hline $\begin{array}{l}\text { ANA } \\
\text { positiv- } \\
\text { ity } \\
(\%) \\
\text { Comorbiditie } \\
(\%)\end{array}$ & $\begin{array}{l}459 / 2348 \\
(19.5)\end{array}$ & $\begin{array}{l}154 / 897 \\
(17.2)\end{array}$ & $\begin{array}{l}104 / 510 \\
(20.4)\end{array}$ & $\begin{array}{l}143 / 701 \\
(20.4)\end{array}$ & $\begin{array}{l}58 / 240 \\
(24.2)\end{array}$ & .071 & 0.104 & 1.000 \\
\hline Gastritis & $\begin{array}{l}339 \\
(7.4)\end{array}$ & $\begin{array}{l}111 \\
(6.2)\end{array}$ & $\begin{array}{l}79 \\
(7.7)\end{array}$ & $\begin{array}{l}108 \\
(8.1)\end{array}$ & $\begin{array}{l}41 \\
(10.2)\end{array}$ & .027 & .040 & .906 \\
\hline
\end{tabular}




\begin{tabular}{|c|c|c|c|c|c|c|c|c|}
\hline Characteris & $\begin{array}{l}\text { Overall } \\
\text { popula- } \\
\text { ticn }\end{array}$ & $\begin{array}{l}\text { Cluster } 1 \\
(\mathrm{n}= \\
\mathbf{1 7 8 6})\end{array}$ & $\begin{array}{l}\text { Cluster 2 } \\
(\mathrm{n}= \\
1031)\end{array}$ & $\begin{array}{l}\text { Cluster 3 } \\
(\mathrm{n}= \\
1332)\end{array}$ & $\begin{array}{l}\text { Cluster } 4 \\
(\mathrm{n}= \\
403)\end{array}$ & ${ }^{*} P$-value & $\begin{array}{l}{ }^{+} P \\
\text { values } \\
\text { for } \\
\text { Cluster } 4 \\
\text { vs }\end{array}$ & $\begin{array}{l}{ }^{+} P \\
\text { values } \\
\text { for } \\
\text { Cluster } 4 \\
\text { vs }\end{array}$ \\
\hline $\begin{array}{l}\text { Allergic } \\
\text { rhinitis }\end{array}$ & $\begin{array}{l}289 \\
(6.3)\end{array}$ & $\begin{array}{l}133 \\
(7.4)\end{array}$ & $\begin{array}{l}86 \\
(8.3)\end{array}$ & $\begin{array}{l}53 \\
(4.0)\end{array}$ & $\begin{array}{l}17 \\
(4.2)\end{array}$ & $<.001$ & .163 & .055 \\
\hline $\begin{array}{l}\text { Drug } \\
\text { allergy }\end{array}$ & $\begin{array}{l}154 \\
(3.4)\end{array}$ & $\begin{array}{l}70 \\
(3.9)\end{array}$ & $\begin{array}{l}43 \\
(4.2)\end{array}$ & $\begin{array}{l}28 \\
(2.1)\end{array}$ & $\begin{array}{l}13 \\
(3.2)\end{array}$ & .017 & 1.000 & 1.000 \\
\hline Asthma & $\begin{array}{l}149 \\
(3.3)\end{array}$ & $\begin{array}{l}59 \\
(3.3)\end{array}$ & $\begin{array}{l}45 \\
(4.4)\end{array}$ & $\begin{array}{l}29 \\
(2.2)\end{array}$ & $\begin{array}{l}16 \\
(4.0)\end{array}$ & .023 & 1.000 & 1.000 \\
\hline $\begin{array}{l}\text { Thyroid } \\
\text { diseases }\end{array}$ & $\begin{array}{l}146 \\
(3.2)\end{array}$ & $\begin{array}{l}59 \\
(3.3)\end{array}$ & $\begin{array}{l}27 \\
(2.6)\end{array}$ & $\begin{array}{l}45 \\
(3.4)\end{array}$ & $\begin{array}{l}15 \\
(3.7)\end{array}$ & .643 & 1.000 & 1.000 \\
\hline Hypertension & $\begin{array}{l}109 \\
(2.4)\end{array}$ & $\begin{array}{l}41 \\
(2.3)\end{array}$ & $\begin{array}{l}28 \\
(2.7)\end{array}$ & $\begin{array}{l}27 \\
(2.0)\end{array}$ & $\begin{array}{l}13 \\
(3.2)\end{array}$ & .477 & 1.000 & 1.000 \\
\hline $\begin{array}{l}\text { Diabetes } \\
\text { mellitus }\end{array}$ & $\begin{array}{l}77 \\
(1.7)\end{array}$ & $\begin{array}{l}26 \\
(1.5)\end{array}$ & $\begin{array}{l}18 \\
(1.7)\end{array}$ & $\begin{array}{l}25 \\
(1.9)\end{array}$ & $8(2.0)$ & .777 & 1.000 & 1.000 \\
\hline
\end{tabular}

Abbreviations: CU, chronic urticaria; H1AH, H1-antihistamine; H2AH, H2-antihistamine; LTRA, leukotriene receptor antagonist; WBC, white blood cell; ESR, erythrocyte sedimentation ratio; BUN, blood urea nitrogen; HDM, house dust mites; ALT, alanine aminotransferase; AST, aspartate aminotransferase; ANA, antinuclear antibody.

*Welch's ANOVA for continuous variables, Pearson's Chi-squared test for categorical variables.

${ }^{+}$Multiple comparisons were corrected by Dunnett's test and Bonferroni correction for categorical and continuous variables, respectively.

TABLE 2 Predictors of remission over 10 years of treatment in patients with chronic urticaria

\begin{tabular}{lll}
\hline Variables & HR $(\mathbf{9 5 \%}$ CI $)$ & $P$-value \\
Age (years) & $0.998(0.995$ to 1.002$)$ & .371 \\
Female & $0.886(0.795$ to 0.988$)$ & .029 \\
Cluster & & \\
Cluster 1 & Reference & Reference \\
Cluster 2 & $0.794(0.698$ to 0.902$)$ & $<.001$ \\
Cluster 3 & $0.463(0.401$ to 0.534$)$ & $<.001$ \\
Cluster 4 & $0.340(0.265$ to 0.436$)$ & $<.001$ \\
Total IgE (kU/L) & $1(1.000$ to 1.000$)$ & .542 \\
Specific IgE to house dust mites $(\mathrm{kU} / \mathrm{L})$ & & \\
$<3.5$ & Reference & Reference?¿? \\
3.5 & $0.731(0.632$ to 0.847$)$ & $<.001$ \\
\hline
\end{tabular}

Abbreviations: HR, hazard ratio; CI, confidence interval.

TABLE 3 Clinical characteristics and medication use according to chronic urticaria relapse

\begin{tabular}{lll}
\hline Variables & Subjects achieving CU remission once & Subjects achieving CU remi \\
\hline & Relapsed $(\mathbf{n}=\mathbf{4 7 0})$ & Not relapsed $(\mathbf{n}=\mathbf{1 9 1 5})$ \\
Age & $36.9 \pm 13.4$ & $38.7 \pm 14.8$ \\
Female $(\%)$ & $281(59.8)$ & $1104(57.7)$
\end{tabular}




\begin{tabular}{lll}
\hline Variables & Subjects achieving CU remission once & Subjects achieving CU remi \\
\hline Combined allergic diseases (\%) & $50(10.6)$ & $183(9.6)$ \\
Use of medications other than H1AH $(\%)^{*}$ & $264(56.2)$ & $955(49.9)$ \\
Systemic steroid use (\%) & $34(7.2)$ & $125(6.5)$ \\
Serum total IgE (kU/L) & $217.3 \pm 318.8$ & $230.3 \pm 386.4$ \\
HDM sensitization [?] class 3 & $74(20.8)$ & $283(18.2)$ \\
\hline
\end{tabular}

Abbreviations: CU, chronic urticaria; H1AH, H1-antihistamines; HDM, house dust mites.

*Medications including omalizumab, cyclosporine, montelukast, H2-antihistamines, and hydroxychloroquine.

Supporting Information TABLE S1 Medication score applied for clustering analysis

\begin{tabular}{lll}
\hline Medication & Dose & Score \\
\hline $\begin{array}{l}\text { H1-antihistamine (equivalent dose } \\
\text { of loratadine) }\end{array}$ & {$[?] 20 \mathrm{mg} /$ day } & 2 \\
& $>20 \mathrm{mg} /$ day & 8 \\
Steroid (equivalent dose of & $<11 \mathrm{mg} /$ day & 5 \\
prednisolone) & $11-25 \mathrm{mg} /$ day & 10 \\
& $>25 \mathrm{mg} /$ day & 15 \\
Cyclosporine & Any dose & 8 \\
Hydroxychlotoquine & & 6 \\
Montelukast & & 2 \\
H2-antihistamine & & 2 \\
Omalizumab & & 12 \\
\hline
\end{tabular}




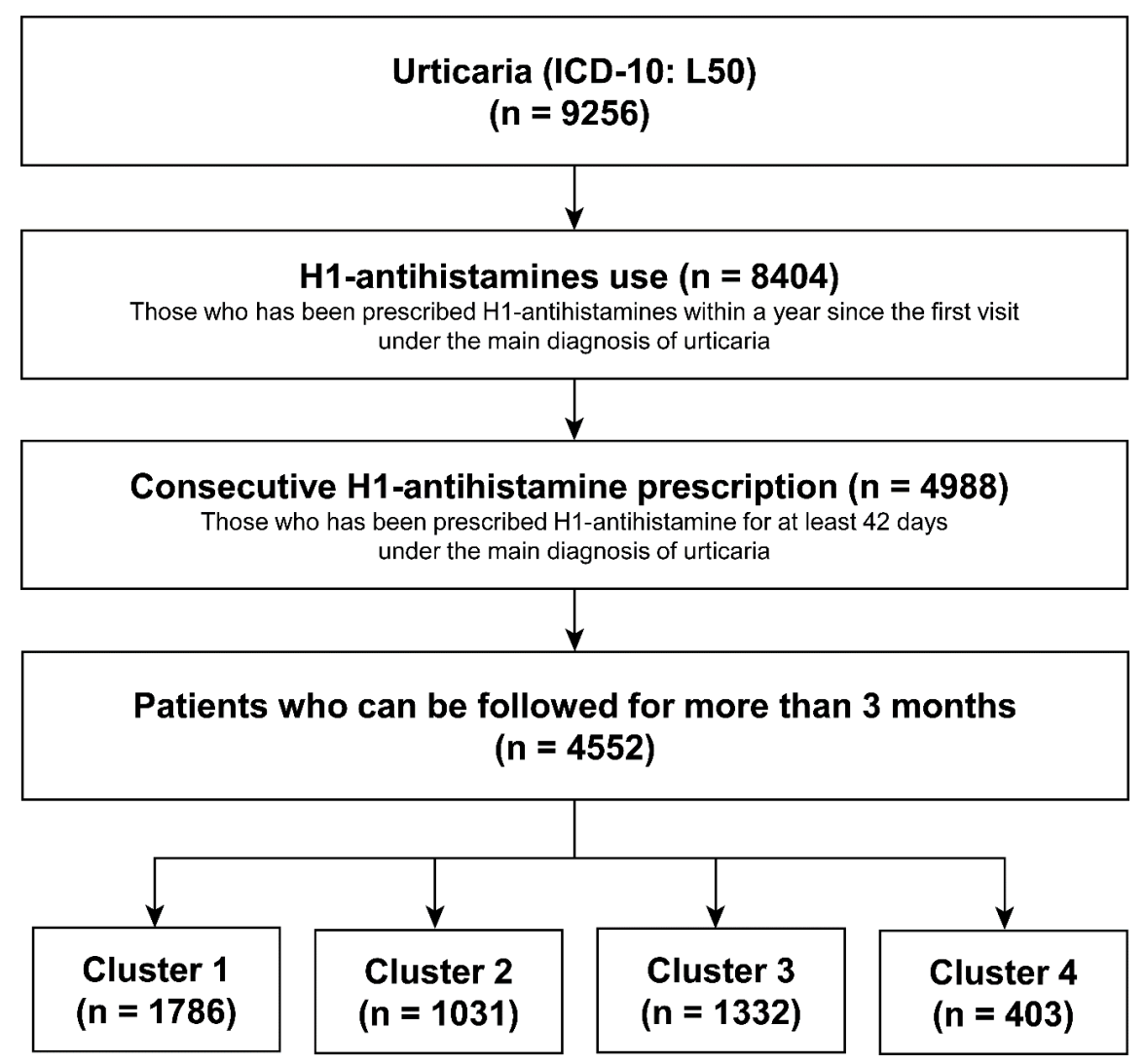

Supporting Information Figure S1

A

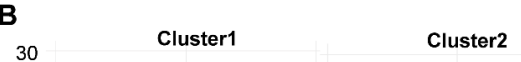

20

20
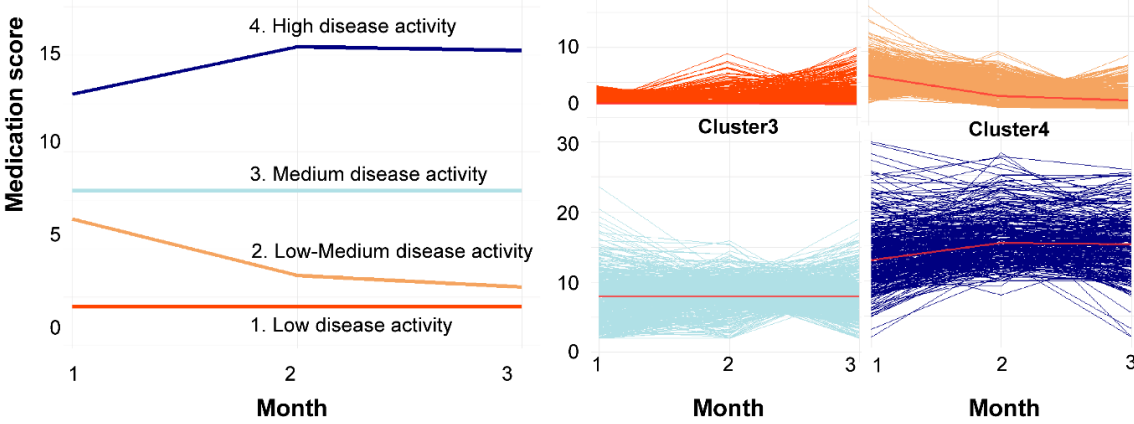

30

Cluster3

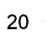

20

10

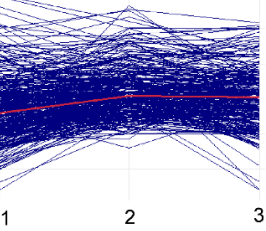

$0_{1}$

Month

Figure 1 


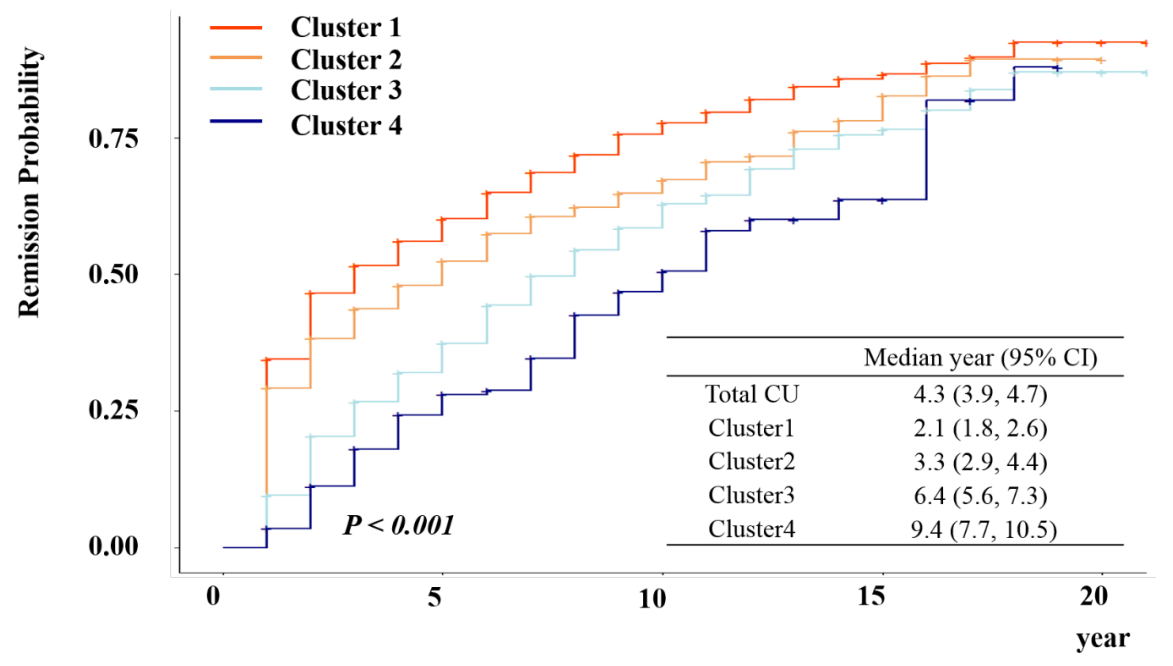

Figure 2

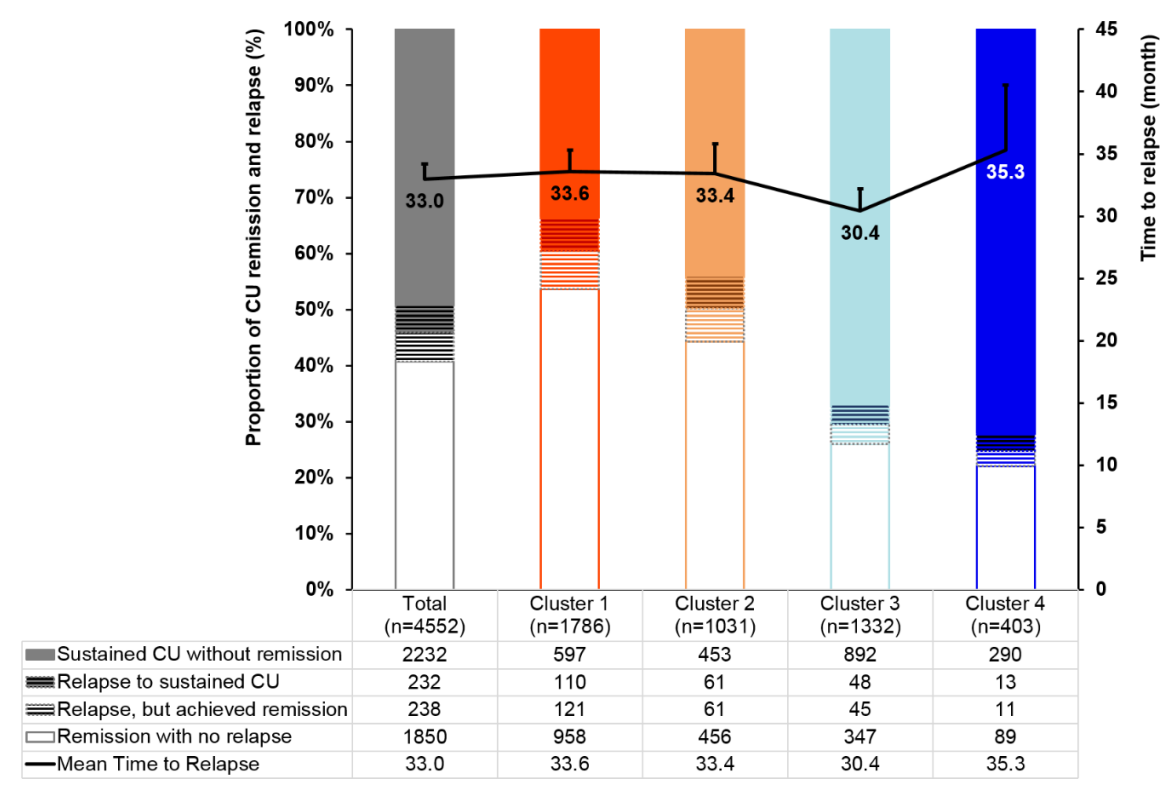

Figure 3

\section{FIGURE LEGENDS}

FIGURE 1 Chronic urticaria clustering with the K-medoids algorithm. Centroids (A) and line plot (B) of clustered groups

FIGURE 2 Kaplan-Meier survival curves for remission from chronic urticaria (CU) among the four CU clusters

FIGURE 3 Proportions of relapsed patients with chronic urticaria (CU) and times to the relapse (mean \pm standard error) among the four CU clusters. sustained CU, CU remission CU relapse

FIGURE S1 Scheme of study subject selection 